\title{
SUPPLY CHAIN RISK MANAGEMENT OF THE SMALL-SCALE INDUSTRY IN WEST SUMATERA
}

\author{
Yuni Ernita*), Rika Ampuh Hadi Guna*), Santosa*), and Nofialdi*) \\ *) Study Program of Agricultural Industry Technology (Science of agricultural), \\ Postgraduate Program of University Andalas \\ Universitas Andalas Road, Limau Manis Kec. Pauh, Padang City, West Sumatera, 25163
}

\begin{abstract}
The existing cacao industry in West Sumatera is a small scale cacao industry. One of the risks encountered in this industry is that the production does not meet the target and the specification set, resulting in the difficulties for the industry to develop. The objective of the research is to conduct a supply chain risk management in the small scale cacao industry in West Sumatera. This research used a survey approach method. While the data collected were primary and secondary data. The supply chain management process used descriptive method and Analytic Network Process (ANP). Study on cacao industry chain supply risk source showed indicates that production risks are in the highest priority with a value of $21.78 \%$. The marketing, financial, institutional and human resource risks have the same priority risk i.e. $19.55 \%$. The highest priority of risk types includes the risk of availability of industrial capital, government policy, skills and personal knowledge, and production process cost, with the priority values of $0.102634 ; 0.101024 ; 0.099903$; and 0.041294 respectively. An alternative risk control priority is to weaken risk (0.39191), and risk segregation (0.25798). Supply chain risk management needs to be held by weakening and segregating risks through improving product management, supply management and information management prioritized on procurement and production processes, thereby enhancing the quality and quantity of processed cocoa products on an ongoing basis. The results of the study can become an input to stakeholders related to the development of smallscale cocoa industry in West Sumatera.
\end{abstract}

Keywords: risk management, supply chain, cocoa industry, small-scale

Abstrak: Industri kakao di Sumatera Barat yang ada adalah industri kakao skala kecil. Salah satu risiko yang ditemui pada industri adalah produksi yang tidak sesuai dengan target dan spesifikasi yang telah ditetapkan, sehingga industri sulit untuk berkembang. Tujuan penelitian adalah melakukan manajemen risiko rantai pasok industri kakao skala kecil di Sumatera Barat. Metode penelitian ini menggunakan pendekatan survey. Data yang dikumpulkan adalah data primer dan data sekunder. Proses manajemen risiko rantai pasok menggunakan metode deskriptif dan Analytic Network Process (ANP). Pengkajian sumber risiko rantai pasok industri kakao menunjukkan bahwa risiko produksi berada pada prioritas utama yang paling potensial terjadi dengan nilai 21,78\%. Sumber risiko pemasaran, finansial, kelembagaan dan SDM merupakan risiko dengan prioritas yang sama dengan nilai 19,55\%. Prioritas jenis risiko yang tertinggi adalah risiko ketersediaan modal industri, kebijakan pemerintah, keterampilan dan pengetahuan personal, dan biaya proses produksi, dengan nilai prioritas masing-masing 0,$102634 ; 0,101024 ; 0,099903 ;$ dan 0,041294. Prioritas alternatif pengendalian risiko adalah melemahkan risiko (0,39191), dan pemisahan risiko (0,25798). Manajemen risiko rantai pasok perlu dilakukan dengan cara melemahkan dan memisahkan risiko dengan meningkatkan manajemen produk, manajemen pasokan dan manajemen informasi yang diutamakan pada proses pengadaan dan produksi, sehingga dapat meningkatkan mutu dan jumlah produk olahan kakao secara berkelanjutan. Hasil kajian dapat menjadi masukan kepada para pemangku kepentingan terkait dengan pengembangan industri kakao skala kecil di Sumatera Barat.

Kata kunci: manajemen risiko, rantai pasok, industri kakao, skala kecil

\footnotetext{
${ }^{1}$ Corresponding author:

Email: yuni.ernita@yahoo.com
} 


\section{INTRODUCTION}

The potency of cocoa development in West Sumatra is very high. The data from West Sumatera Plantation Office (2016) showed a total land area of cocoa in 2015 in West Sumatera reached $155,994 \mathrm{Ha}$ or $9 \%$ of total land area in Indonesia with production of 52,917 tons. When a community is able to develop their region potency then the region will become more profitable. The care of the potential of the region will become a profitable thing if the community can develop the potency (Risdayani, 2016). Moreover the development of the plantation area also increases the role of smallholder in agricultural development (Zulfiandri and Marimin, 2012).

The development of cocoa plantations in West Sumatra has not been supported by the development of the cocoa industry. Cocoa commodity is still exported in the form of dry cocoa beans due to the small number of existing cocoa bean processing business. The central and regional governments have been providing cocoa processing units, but the cocoa industry in West Sumatra still operates on small-scale cocoa industry as Coklat Adam and Chokato. Coklat Adam Industry is located in Padang Pariaman Regency and has the capacity of of producing $20 \mathrm{~kg} /$ day while Coklat Chokato Industry is located in Payakumbuh City and is able to produce of $20 \mathrm{~kg} /$ day.

The development of the cocoa processing industry needs to be implemented in order to increase added value, boost economic growth, increase employment and boost foreign exchange earnings from export of cocoa processing products (Syadullah, 2012). The government needs to regulate the development of the cocoa bean processing industry, so that local industries can compete with foreign investor (Putri et al. 2014). Various policies are implemented by the government to support the increase of cocoa industry investment. The Government issued a policy of export duty through the Regulation of the Minister of Finance No. 67 of 2010 on Stipulation of Export Goods Subject to Export Levy and Export Duty Tariff. This policy has an impact on changes in the composition of Indonesian cocoa exports (Rifin, 2012). The enforcement of this policy is also effective in reducing the export volume of cocoa beans, inceasing the industrial performance, and export of processed cocoa (Haifan, 2015). The non-tariff policy applied by the cocoa seed importing countries contributes to the downstream program and the decline of cocoa seed exports (Sinuriya et al. 2017).
Cocoa industry has been operated, but it is not optimal enough because it is still operating in undercapacity (Mulyono, 2016). The government, producer farmers and processing plants need to be linked in order to develop the cocoa industry, The development of the cocoa industry needs to be connected among the government, producer farmers and processing plants (Listyati et al. 2014). According to Zulfiandri and Marimin (2012), the factors to be considered in the development of the cocoa industry include the economic aspects, especially the availability of raw materials and government policies. These factors are the risk to the members of the cocoa processing industry supply chain.

The definition of risk according to Djohanputro (2008), is an uncertainty of what is known about its occurrence probability that can cause deficit or loss. Uncertainty is a condition that causes the growth of risk. Sources of risk include events that cause direct financial losses and indirect losses (Hadiguna, 2015). Types of risk according to Agriculture and Rural Development World Bank (2011) include quality, production risk, price risk, supply risk, environmental risk, and transportation risk.

The supply chain according to Hadiguna (2015) is a collection of sequential supply process which fills the targets and begins from upstream to downstream. A supply chain consists of a series of decision-making and execution process that is related to the flow of materials, information, and capital. There has been several studies related to supply chain risk include mitigating risk in the supply chain of cocoa agro-industry using Severity Index (Iphov et al. 2014). Aini et al. (2013) analyzed the risk of cocoa supply chain with ANP and Failure Mode Effect methods. The cocoa industry faces several global challenges and issues including the various risks involved in the cocoa supply chain, and these risks can affect the supply chain flow. Ulfah et al. (2016) analyzed and improved the supply chain risk management in refined sugar using the House of Risk approach.

The risk management cycle according to Djohanputro (2008) consists of risk identification, risk measurement, risk mapping, risk management model, monitor, and control. Risk identification should be made of all risks and sources, within or outside the organization. Risk measurement refers to two factors, namely, the quantity and quality of risk factors. Risk mapping principally is a risk-making based on certain groups. Risk management 
is implemented through coordination and collaboration among partners in the supply chain (Tang, 2006). Risk monitoring and aim controlling are to ensure that the implementation of the risk management process is in accordance to the plan, to make sure that the implementation is effective, and to monitor the progress against the trend towards changing risk profile.

The impact of supply chain risk can be reduced by coordinating and collaborating processes with four basic approaches: supply management, inventory, product, and information. Coordination and collaboration with the four basic approaches in the company are called Operational Key Process (OKP). OKP is one strategy which aims at reducing the impact of supply chain risk (Simanjuntak, 2013).

Presently, the development of small-scale cocoa industry in West Sumatra faces several challenges and problems including the various risks involved in the cocoa industry supply chain. One of these risks is that the production is not in accordance with the targets and specifications that have been set. This is due to the high cost of production process as a result from the limited capacity of cocoa processing machinery. Based on this, it is necessary to conduct a research in the risk management of small-scale cocoa industry supply chain in West Sumatera. Supply chain risk management can improve the quality and quantity of processed cocoa products and it also as an effort to increase the competitiveness and development of small-scale cocoa industry in West Sumatra.

\section{METHODS}

The research method used a survey approach. The data collected were primary and secondary data. The primary data were obtained through observations and direct interviews with the parties involved in the supply chain (20 cocoa farmers, 8 cocoa farmer groups, 6 collecting merchants, 2 wholesalers, 2 cocoa industries, 2 food and beverage industries, and 2 exporters) at all districts of cocoa production centers of West Sumatra. Secondary data were obtained through literature review, studying reports and data from relevant offices/agencies. The experts were selected from the academics, bureaucrat, and practitioners associated with the cocoa supply chain.
Risk management is a logically and systematically arranged method of a series of activities. To conduct a chain management of the cocoa industry in the supply chain, the kind of source and the type of risk are needed, the supply chain, is important to know the risk factors that may influence the supply chain management of the cocoa industry, so solutions can be established, or a supportive strategy for enhancing the capability of the chain management for cocoa industry supply chain can be applied.

The methods used in the risk management process were descriptive and ANP methods. Descriptive method is used for exploration on supply chain of cocoa processing industry. The ANP method is used to evaluate and control the risk. According to Saaty (2006), ANP is an analytical tool that is able to represent the importance of various parties by considering the dependency relationship between the criteria and sub criteria. The ANP method is used to see the interaction of high dependency between the risk type and supply chain risk factors. Then the risk priority and alternative risk control options can be accurately determined to make better decisions. The framework of research thinking can be seen in Figure 1.

According to Izik et al. (2011), the ANP solution process has four major steps:

\section{Develop a model decision structure}

In this step, problem-solving and conceptual modeling is carried out. The results of questionnaires from several respondents are combined to determine whether there is a relationship of interdependence between these criteria with the following formula:

$$
\mathrm{Q}=\mathrm{N} / 2
$$

If $\mathrm{Vij}>\mathrm{Q}$, then there is a relationship of interdependence between criteria. If $\mathrm{Vij}<\mathrm{Q}$, then there is no interdependence relationship between criteria.

While: $\mathrm{N}$ (Number of respondents or decision makers); $\mathrm{Q}$ (The middle value of the number of respondents or decision makers); Vij(Number of respondents who choose a relationship of interdependence between criteria on cells connecting row $i$ with column $j$ ). 
2. Matched pairwise matrices of interrelated variables

In the second stage the group and the elements will be compared according to the controlled criterion using the fundamental comparison scale in Table 1. The next stage is pair comparising between the groups / elements to decrease the eigen vector, and form the supermatrix. A pairwise comparison is done by making a pairwise matrix of comparison, with aij representing the relative importance value of the element in row (i) to the element in column (j). For example aij $=w i / w j$. Next we make the priority weight vector $(\mathrm{w})$ calculated by the formula:

$$
\mathrm{Aw}=\lambda \max \mathrm{w}
$$

While: $\lambda$ max (eigen value (characteristic value of the largest $\mathrm{n} \times \mathrm{n}$ matrix) in matrix A); $\mathrm{w}$ (eigen vector (nonzero column vector which, when multiplied by an $\mathrm{n} x \mathrm{n}$ size matrix, gives another vector that has a multiple of the eigen vector itself)).

Comparison of the pairs of elements in each level is made to the relatively importance for the control criterion. The correlation matrix is arranged based on a scale of 1-9. In the assessment process, problems can occur in consistency of pairwise comparisons. The inconsistency limit set by Thomas L. Saaty is not more than $0.1(\mathrm{CR}<0.1)$. The Consistency Index $(\mathrm{CR})$ and Consistency Ratio (CR) of the matrix are calculated by equation:

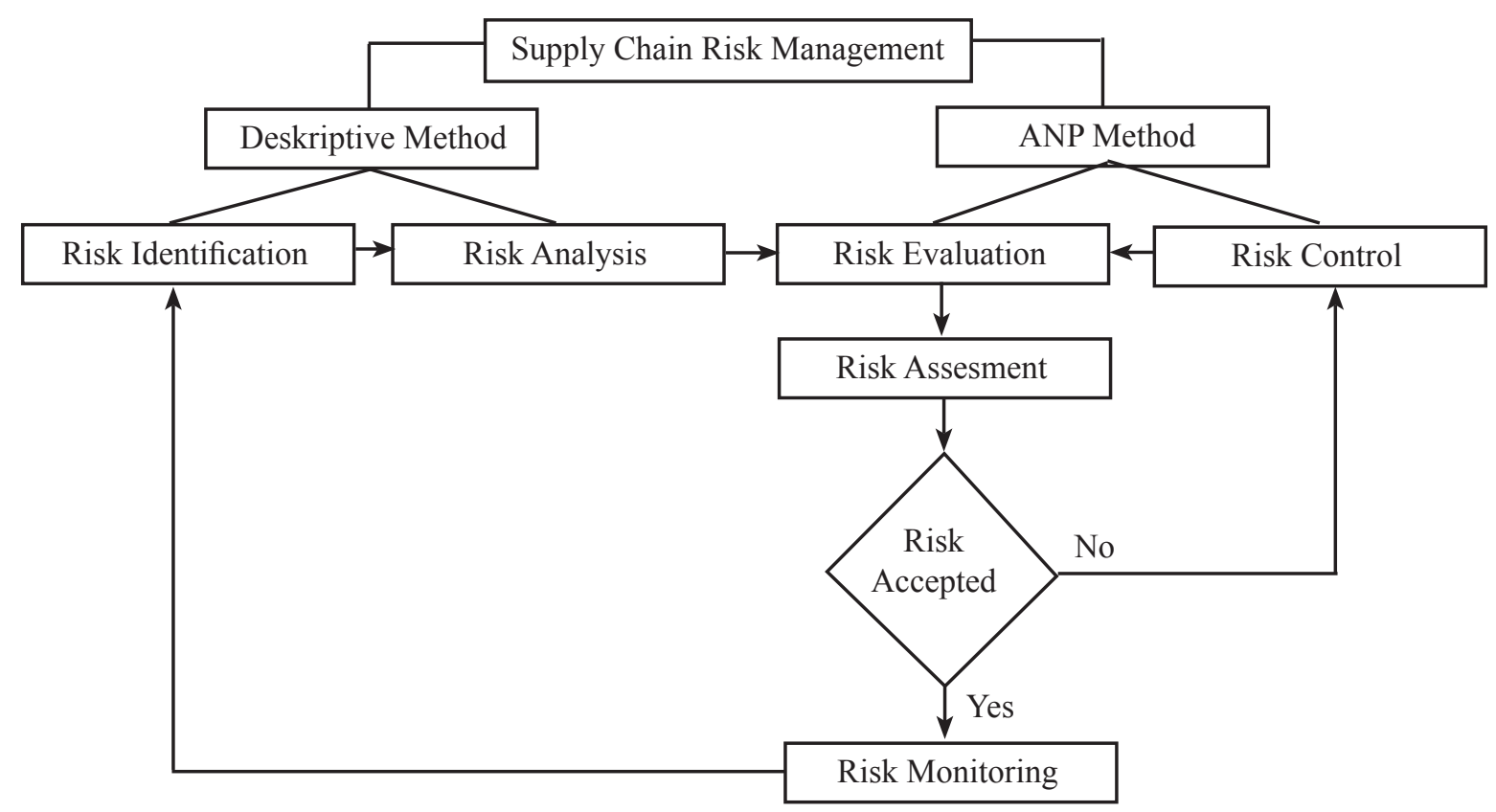

Figure 1. Research framework

Table 1. Fundamental comparison scale

\begin{tabular}{|c|c|c|}
\hline Level & Definition & Explanation \\
\hline 1 & Both elements are equally important & Two elements have the same effect on the goal \\
\hline 3 & $\begin{array}{l}\text { The one element is a little more important than } \\
\text { another element }\end{array}$ & $\begin{array}{l}\text { Experience and judgment slightly support one element over } \\
\text { the other }\end{array}$ \\
\hline 5 & $\begin{array}{l}\text { The one element is more important than the } \\
\text { other }\end{array}$ & $\begin{array}{l}\text { Experience and judgment strongly support one element over } \\
\text { another }\end{array}$ \\
\hline 7 & $\begin{array}{l}\text { The one element is clearly more important than } \\
\text { the other }\end{array}$ & One element is strongly supported and dominant in practice \\
\hline 9 & $\begin{array}{l}\text { The one element is absolutely more important } \\
\text { than the other }\end{array}$ & $\begin{array}{l}\text { Evidence that supports one element against another has the } \\
\text { highest degree of affirmation that might be corroborating }\end{array}$ \\
\hline $2,4,6,8$ & $\begin{array}{l}\text { Values between two adjacent consideration } \\
\text { values }\end{array}$ & $\begin{array}{l}\text { This value is given when there is a compromise between two } \\
\text { options }\end{array}$ \\
\hline $\begin{array}{l}\text { The } \\
\text { opposite }\end{array}$ & Reciprocals & $\begin{array}{l}\text { If for activity } i \text { gets one number when compared with activity } \\
j \text {, then } j \text { has the opposite value when compared with activity } i\end{array}$ \\
\hline
\end{tabular}




$$
\begin{gathered}
\mathrm{CI}=((\lambda \max -\mathrm{n})) /((\mathrm{n}-1)) \\
\mathrm{CR}=\mathrm{CI} / \mathrm{RI} \quad<0,1
\end{gathered}
$$

While: CI (Consistency index); $\lambda \max$ (Maximum eigenvalues in the matrix); $\mathrm{n}$ (number of matrices); CR (Consistency ratio); RI (Random index); the consistency threshold of 0.1 to assess whether the comparison is consistent (if $\mathrm{CR}<0.1=$ consistent).

\section{Calculation of supermatrix}

Supermatrix calculations are performed by three steps, namely: Unweight Supermatrix, Weighted Supermatrix, and Limiting Supermatrix.

\section{The weight of interest of clusters and nodes}

Determined the importance weights of the determinants factor by using the Limiting Supermatrix results from the ANP model. The overall priority of each alternative is calculated through synthesis. The results obtained from each sub network are synthesized to obtain the overall priority of the alternatives. The synthesis results from this priority are normalized to select the highest priority alternative.

\section{RESULTS}

\section{Identification of Cocoa Industry Supply Chain}

Supply chain identification is conducted to determine the supply chain stages of the cocoa industry from upstream to downstream by determining the structure and members of the cocoa industry supply chain.

\section{Cocoa Industry Supply Chain Structure}

The structure of the cocoa industry chain describes the members and roles of each member of the supply chain, and illustrates the elements of the supply chain that plays a role in the business process. The structure of the cocoa industry supply chain is the actors involved in the flow of products, finances, and information from producers to the final consumers. The chain structure of the cocoa industry in West Sumatra is presented in Figure 2.

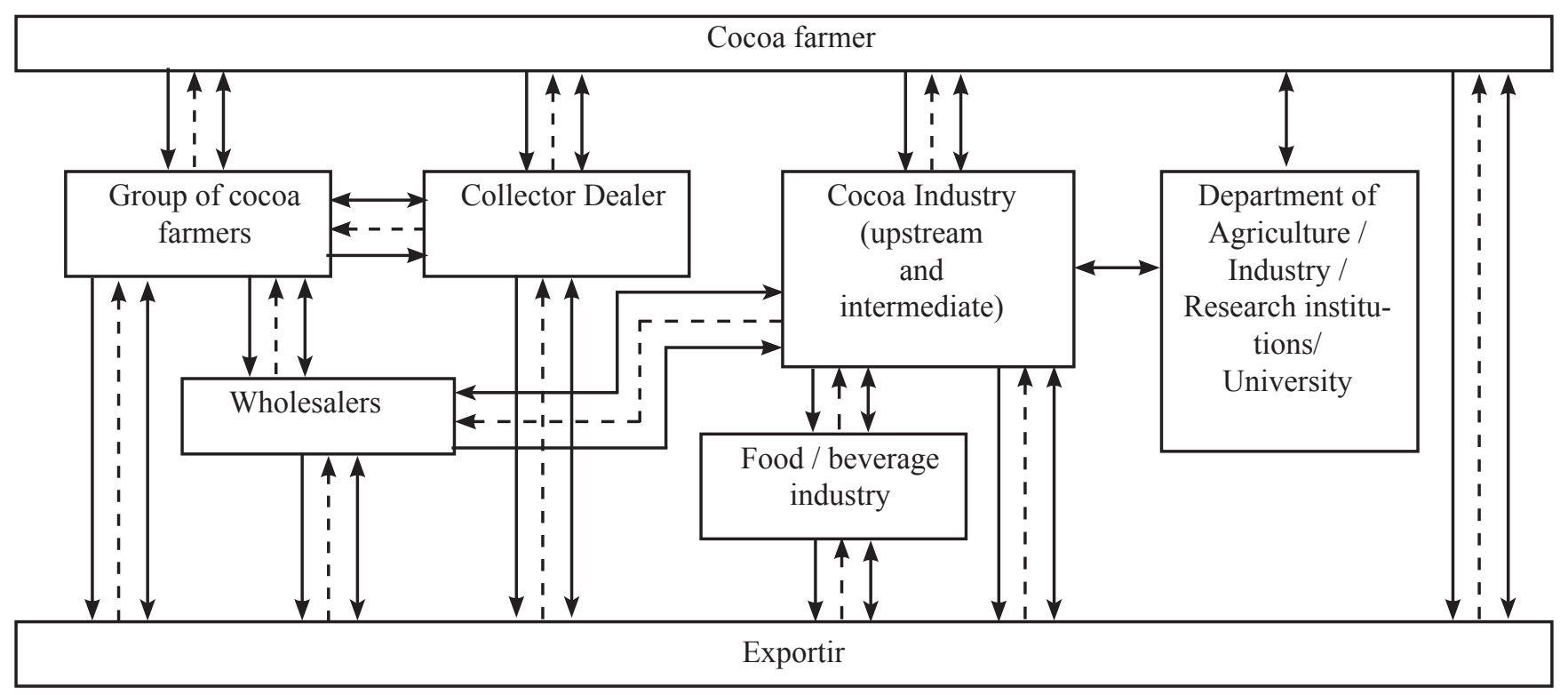

Figure 2. Structure of cocoa industry supply chain : Materials, : Informations) 
Member of Cocoa Industry Supply Chain in West Sumatera

The result of paired comparison to determine the necessity weight of cocoa industry's supply interest in West Sumatera is presented in Figure 3. Cocoa farmer is a member of the first supply chain in cocoa industry that has an important role in cocoa supply (quality, quantity and availability of cocoa beans) with weight 0.197 . The selling price of cocoa beans at the farm level is influenced by the quality of the produced cocoa beans (Herawati et al. 2015). The cocoa industry is a member of the second most important supply chain after the cocoa farmer weighs 0.168 . Industry has a high degree of dependence on quality of cocoa related to consumer choice and demand. The food and beverage industry ranks third in the cocoa supply chain with a weight of 0.114 . Products from the cocoa industry are processed by the food and beverage industry into a wide range of products.

The collecting trader is a member of the supply chain with an interest rate of 0.101 . Collecting traders play a role in collecting cocoa beans from farmers. The next sequence is followed by a wholesaler with a weight of 0.096. Wholesalers are members of the last supply chain on marketing activities. Wholesalers generally do the sorting process before selling to exporters (Hasibuan et al. 2015). The next supply chain is a cocoa farming group with a weight of interest of 0.081 . The cocoa farmer group plays a role in managing the administration and determining the direction of cocoa supply chain management performance.
The development of cocoa processing industry is inseparable from cooperation with several supporting institutions such as Agriculture and Estate Crops (0.062), Industry and Trade Agency (0.059), and universities $(0,053)$. Supporting institutions and universities play a role in providing guidance and assistance, policy support, research facilities and facilities, access convenience, innovation and technology transfer cooperation. The member of the supply chain with the lowest interest is an exporter with a weight of 0.050 . This is because consumers of cocoa industry products in West Sumatra are still limited to local consumers, while the role of exporters in the supply chain is as a liaison with consumers abroad.

\section{Risk Characteristics}

Characteristic of risk is the stage of risk management process undertaken by identifying and analyzing cocoa industry supply chain risk.

\section{a. Identification of Risk}

The identification of cocoa industry supply chain risk is applied to all types of risks and sources both within and outside the organization. Identification is also conducted on risk drivers in improving the supply chain management capability of cocoa. Identification of some potential risks in the cocoa supply chain in West Sumatra needs to be done to understand the linkages between alternative risk controls and other factors in managing those risks.

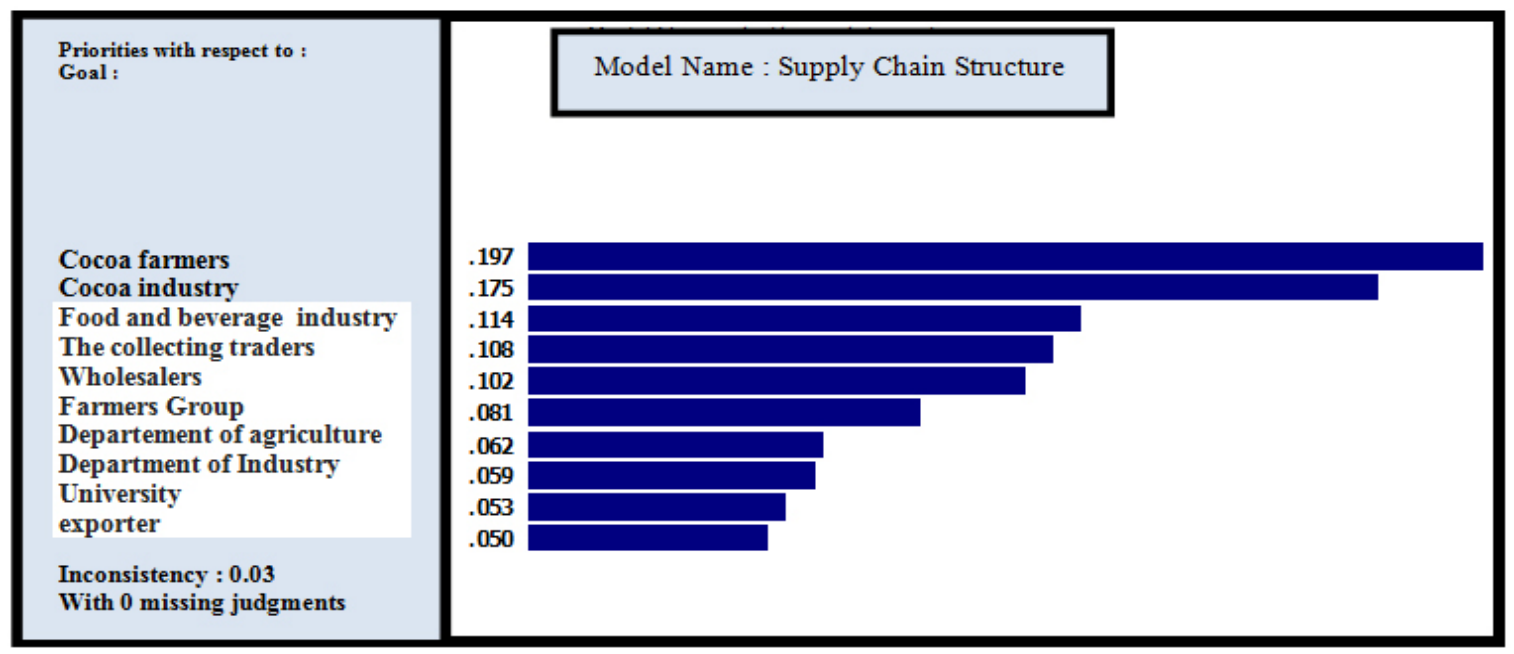

Figure 3. Pairwise comparison of supply chain interests weight 


\section{b. Analysis of Risk}

Analysis of risk is performed to assess the source of risk, the types of risks, risks factor, chances and impacts. After identifying potential sources of risk and potential risk analysis, prioritizing risk sources and then risk factor analysis and risk control alternatives. Details is presented in in Table 2.

\section{Risk Evaluation and Control}

Evaluation of risk is comparing the level of risk that has been calculated in the risk analysis stage with the used standard criteria. The result of the Implementation of evaluation and control of risk by using ANP method is the priority of potential risk and priority of factors that support SCRM capability in which there is priority of risk control in supply chain of cocoa industry in West Sumatera. The final priority result of the ANP method is the limit value and the normalized value is shown in Table 2.

Table 2. Results of ANP risk supply chain management of small scale cocoa industry in West Sumatra

\begin{tabular}{|c|c|c|c|}
\hline & Information & Normalized by klaster & Limiting \\
\hline \multicolumn{4}{|l|}{ A. Source of Risk } \\
\hline Production Risk & $\begin{array}{l}\text { Procurement of raw materials } \\
\text { Performance of machinery and process equipment } \\
\text { Level of process efficiency } \\
\text { Process costs } \\
\text { Failure rate of achievement of quality } \\
\text { Quality and safety of the product } \\
\text { Storage process }\end{array}$ & $\begin{array}{l}0.14831 \\
0.11838 \\
0.11707 \\
0.18958 \\
0.14112 \\
0.18330 \\
0.10225\end{array}$ & $\begin{array}{l}0.032305 \\
0.025785 \\
0.025499 \\
0.041294 \\
0.030738 \\
0.039925 \\
0.022272\end{array}$ \\
\hline Marketing Risk & $\begin{array}{l}\text { Uncertainty of price } \\
\text { Uncertainty of demand } \\
\text { Uncertainty of delivery } \\
\text { Consumer satisfaction } \\
\text { Conditions of competition } \\
\text { Distribution system }\end{array}$ & $\begin{array}{l}0.21056 \\
0.15890 \\
0.16683 \\
0.15532 \\
0.15499 \\
0.15348\end{array}$ & $\begin{array}{l}0.041174 \\
0.031073 \\
0.032623 \\
0.030354 \\
0.030308 \\
0.030013\end{array}$ \\
\hline Financial Risk & $\begin{array}{l}\text { Exchange rate fluctuations } \\
\text { availability of industrial capital }\end{array}$ & $\begin{array}{l}0.47514 \\
0.52486\end{array}$ & $\begin{array}{l}0.092911 \\
0.102634\end{array}$ \\
\hline Institutional Risks & $\begin{array}{l}\text { government policy } \\
\text { Business relationships between business actors }\end{array}$ & $\begin{array}{l}0.51663 \\
0.48337\end{array}$ & $\begin{array}{l}0.101024 \\
0.094522\end{array}$ \\
\hline Risk of Human Resources & $\begin{array}{l}\text { Prosperity of the perpetrators } \\
\text { Personal skills and knowledge }\end{array}$ & $\begin{array}{l}0.48910 \\
0.51090\end{array}$ & $\begin{array}{l}0.095642 \\
0.099903\end{array}$ \\
\hline \multicolumn{4}{|l|}{ B. Factor Risk } \\
\hline $\begin{array}{l}\text { Operational Key Process } \\
\text { (OKP) }\end{array}$ & $\begin{array}{l}\text { Supply Management } \\
\text { Demand Management } \\
\text { Production Management } \\
\text { Information Management }\end{array}$ & $\begin{array}{l}0.29603 \\
0.11342 \\
0.40245 \\
0.18810\end{array}$ & $\begin{array}{l}0.156436 \\
0.059935 \\
0.212676 \\
0.099402\end{array}$ \\
\hline $\begin{array}{l}\text { Operational Process Cycle } \\
\text { (OPC) }\end{array}$ & $\begin{array}{l}\text { Procurement } \\
\text { Production } \\
\text { Distribution } \\
\text { Logistics } \\
\text { Service }\end{array}$ & $\begin{array}{l}0.39347 \\
0.26930 \\
0.16939 \\
0.06514 \\
0.10271\end{array}$ & $\begin{array}{l}0.105418 \\
0.072151 \\
0.045382 \\
0.017451 \\
0.027518\end{array}$ \\
\hline $\begin{array}{l}\text { Organization Performance } \\
\text { Factor (OPF) }\end{array}$ & $\begin{array}{l}\text { amount } \\
\text { Quality } \\
\text { Cost } \\
\text { Time }\end{array}$ & $\begin{array}{l}0.28086 \\
0.44670 \\
0.10080 \\
0.17165\end{array}$ & $\begin{array}{l}0.038149 \\
0.060675 \\
0.013691 \\
0.023315\end{array}$ \\
\hline \multicolumn{4}{|l|}{ C. Alternative Risk Control } \\
\hline $\begin{array}{l}\text { Risk Operational Process } \\
\text { (ROP) }\end{array}$ & $\begin{array}{l}\text { Separation } \\
\text { Transfer } \\
\text { Insurance } \\
\text { Dodge } \\
\text { Weaken }\end{array}$ & $\begin{array}{l}0.25414 \\
0.11245 \\
0.06314 \\
0.15913 \\
0.41114\end{array}$ & $\begin{array}{l}0.017231 \\
0.007624 \\
0.004281 \\
0.010789 \\
0.027876\end{array}$ \\
\hline
\end{tabular}




\section{Risk Source and Risk Analysis}

Assessment of the source of small-scale cocoa industry supply chain risk in West Sumatera shows that production risks are in the most potential priority with a value of $21.78 \%$. This is due to the limited facilities and infrastructure in terms of the low performance of the machinery and equipment production process is low and resulting the inability of the production to reach the determined targets and specifications. Production risks can cause harm if the problem solving could not be done to that risks (Fanani et al. 2015). Production risks can be detrimental to the achievement of the goals and objectives of the business organization (Irawan et al. 2017). Sources of marketing, financial, institutional and HR risk are in the same priority risk with $19.55 \%$.

The highest priority of risk types is the risk of availability of industrial capital, government policy, skills and personal knowledge, production process cost, and price uncertainty with priority value of $0.102634 ; 0.101024$; $0.099903 ; 0.041294$; and 0.041174 . These five types of risks are the most potential risks and need to be first solved to improve supply chain risk management capability of small-scale cocoa industry in producing strong supply chain management.

The result of ANP analysis at OKP indicates that Product Management is the most important factor (40\%) (Figure 4) in key processes operational influencing. The improvement of product management in the cocoa industry is done in managing the production process. Management is performed on the performance of machinery and process equipment, the level of cocoa processing efficiency, the control of failure rate of quality achievement, product quality and safety as well as management in the process of storage of processed cocoa products. Product management in the cocoa industry is very influential on the final quality and selling price of cocoa processed products. Good quality will be produced from good process and in accordance to the quality standards that have been determined based on market requirements (Darsono, 2013).

The supply management factor $(30 \%)$ is of concern. Supply management and product management demonstrate a strong linkage between the two factors on influencing the small-scale cocoa industry operations process in West Sumatra. Supply management largely determines the availability of raw materials in terms of quantity, quality, and continuities of raw materials. High or low production of processed cocoa will affect the income and profitability of the cocoa industry therefore it is necessary for supply the management to look after the availability of raw materials of cocoa. Information management (19\%) is closely related to the collection and distribution of information in improving the quality of processed cocoa products. Information on processing, packaging, product storage until the stage of rapid distribution, improvement of logistics processes and service processes. The final demand management factor in the Operational Key Process cluster (OKP). The demand management factor needs to be done to manage the business of fulfilling consumer demand in accordance with the quantity and quality of the appropriate cocoa products. According to Nasution and Yasin (2014), the development of demand from a product can be related to price, especially in the increasingly keen competition.

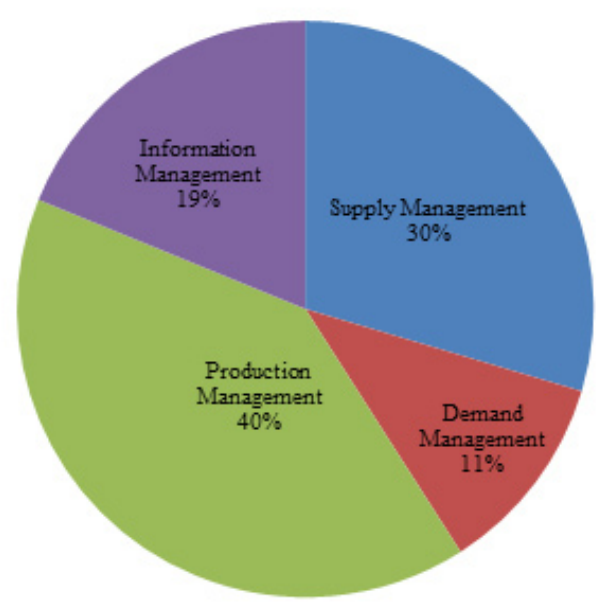

Figure 4. Priority of Operational Key Process (OKP) 


\section{Results of Risk and Alternative Risk Analysis}

The priority value of the managerial element or the supporting factor indicates that the Operational Key Process is the primary managerial part $(0.528449)$ to improve the management of the supply chain risk of small-scale cocoa industry in West Sumatra.

Further improvement in the cocoa industry needs to be done on the operational process cycle (OPC) factor (0.26792). The primary ingredient that needs to be improved is procurement (39\%) (Figure 5). The procurement factor becomes the first priority in influencing the operational cycle process; the raw material procurement factor that is considered is the cocoa raw material in accordance with SNI. Procurement decisions will affect the production and quality of processed cocoa products. The next factor to consider is Production (27\%). Based on the data in the field where the production of processed cocoa products in small industries in West Sumatra is very limited because the production process depends on the ability of the process, machine stability, and skills of the employee. These elements can affect the quality of the results and the accuracy of shipment within the cocoa industry supply chain. Furthermore, the distribution, service and logistic factors with the percentage of respectively $17 \%, 10 \%$ and $7 \%$.

Further improvements were made to the Organization Performance factor (OPF) (0.13583) to minimize and prevent supply chain risk after making improvements to both key factors (OKP and OPC). Improvements were made by improving quality $(45 \%)$, production (28\%), timeliness of production (17\%), and production cost $(10 \%)$. Among the OPF clusters in cocoa industry risk management in West Sumatra the most important was the quality (Figure 6). Uncontrolled quality in the production of processed cocoa products will affect the consumer satisfaction. Indirectly it will reduce revenue because some of the consumers will move on to other cocoa processed products manufacturers. Total production is the second important factor after quality. Attentions to the amount of production is important in the fulfillment of consumer needs, then consider the time and cost factors.

Risk operational process (ROP) is the last factor in chain management of cocoa industry supply chain $(0.067801)$. The analysis results revealed that the sequence of risk control to be performed on the supply chain of cocoa industry is to weaken the risk (41\%), risk segregation $(26 \%)$, risk aversion (16\%), risk transfer $(11 \%)$, and risk insurance (6\%) (Figure 7).

Alternative risk control is closely related to the consideration of the amount of costs incurred and the profit opportunities that will be obtained. Weakening risk is the most likely alternative risk control, because it has a greater chance of profit than avoiding, segregating, transfer or risk insurance (Simanjuntak, 2013).

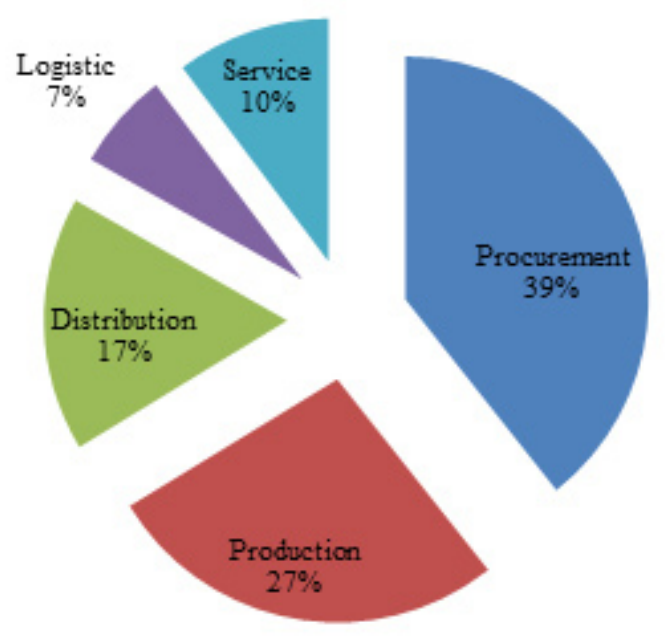

Figure 5. Priority of Operational Process Cycle (OPC) 


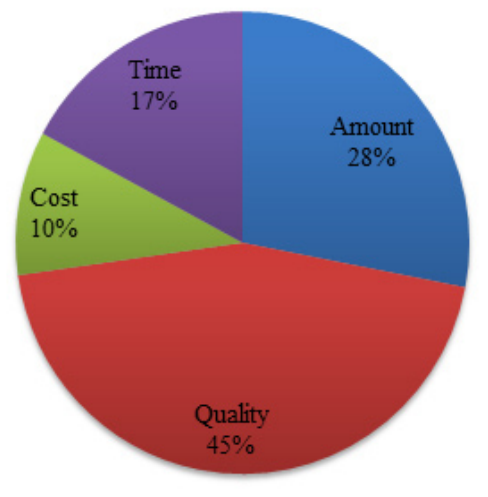

Figure 6. Priority organization performance factor (OPF)

\section{Managerial Implications}

The managerial implications of small-scale cocoa industry supply chain management in West Sumatera are efforts to improve the quality and quantity of processed cocoa products. Some risk control processes that can be implemented are alternative controls in the form of weakening and separating risk by means of product management, supply management and information management.

The process of improving product management relates to the management of production processes conducted in accordance with Standard Optional Procedures (SOP). Management is performed on the performance of machinery and process equipment, the level of cocoa processing efficiency, the control of failure rate of quality achievement, product quality and safety as well as the process of storage of processed cocoa products. The managerial implications of the supply management process are carried out by encouraging farmers as a supply partner to form a farmer's group, and will be facilitated coaching by the local government. Coaching is done to meet the quality improvement of cocoa. The process of information management is concerned with the collection and distribution of information to improve the quality of processed cocoa products. Information on processing, packaging, product storage, to the stage of rapid distribution, improvement of logistics processes and service processes. In the process of procurement of cocoa that is considered is the raw material of cocoa in accordance with SNI. This will reduce the quality uncertainty and increase the number of processed cocoa products.

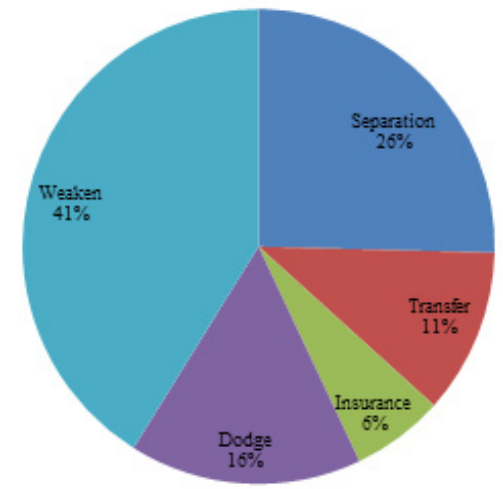

Figure 7. Priority Risk Operational Process (ROP)

The successful management of this small-scale cocoa industry supply chain risk will form a powerful supply chain that reduces risk, thereby enhancing the welfare of small-scale cocoa industry entrepreneurs in West Sumatra.

\section{CONCLUSIONS AND RECOMMENDATIONS}

\section{Conclusion}

The management of small-scale cocoa industry supply chain risk in West Sumatra is done by identifying supply chain risk. Risk identification results in a clear assessment about possibility and causes of risks in order for businesses to anticipate potential risks. ANP analysis results indicate that the potential source of supply chain risk is production risk, while the source of marketing, financial, institutional and human resources risk is the same priority risk. The highest priority of risk types is the risk of availability of industrial capital, government policy, skills and personal knowledge, and production process costs. Evaluate each risk in order to obtain an alternative action to anticipate the risk.

Risk control is done by weakening and segregating risk byimprovingproductmanagement, supplymanagement, and information management. Improvement of product management is done on the production process. Supply management improvements are made on the availability of raw materials (quantity, quality, and continuities). Improved management of information related to the collection and distribution of information to improve the quality of processed cocoa products. 


\section{Recommendations}

The results of the review are suggested as inputs to the stakeholders related to the development of small-scale cocoa industry in West Sumatra.

\section{REFERENCES}

Aini H, Syamsun M, Setiawan A. 2013. Risiko rantai pasok kakao di Indonesia dengan metode analytic network process dan failure mode effect analisis terintegrasi. Jurnal Manajemen \& Agribisnis 11(3): 209-219.

Agriculture and Rural Development World Bank. 2011. Supply Chain Risk Assessment Cocoa in Ghana. Washington D.C: The World Bank.

Darsono. 2013. Analisis pengendalian kualitas produksi dalam upaya mengendalikan tingkat kerusakan produk. Jurnal Ekonomi-Manajemen 35: 1-17.

Djohanputro B. 2008. Manajemen Risiko Koorporat Terintegrasi. Jakarta: PPM.

Fanani A, Anggraeni L, Syaukat Y. 2015. Pengaruh kemitraan terhadap risiko usaha tani tembakau di Kabupaten Bojonegoro Provinsi Jawa Timur. Jurnal Manajemen \& Agribisnis (12)3: 194-203. https://doi.org/10.17358/JMA.12.3.194.

Hadiguna RA. 2015. Manajemen risiko rantai pasokan: pergeseran orientasi bersaing dalam perspektif sistem. https://www.researchgate.net/ publication/284733300. [19 Oktober 2017].

Haifan M. 2015. Dampak kebijakan bea keluar terhadap kinerja industri pengolahan kakao. Jurnal IPTEK (1) $1: 1-6$.

Hasibuan AM, Wahyudi A, Listyati D, Aunillah A, Ermiati, Herman M. 2015. Peran organisasi petani dalam mengoptimalkan kinerja rantai pasok dan pembentukan nilai tambah kakao: studi kasus di Kabupaten Kolaka Sulawesi Tenggara. Jurnal Tanaman Industri dan Penyegar (2)1: 1-12.

Herawati, Rifin A, Tinaprilla N. 2015. Kinerja dan efisiensi rantai pasok biji kakao di Kabupaten Pasaman Sumatera Barat. Jurnal Tanaman Industri dan Penyegar (2)1: 43-50.

Iphov KS, Yandra A, Dahrul S, Marimin. 2014. Analisis dan mitigasi risiko rantai pasok agroindustri kakao yang berkelanjutan. Jurnal Industri Hasil Perkebunan (9)2: 69-79.

Irawan JP, Santoso I, Mustaniroh SA. 2017. Model analisis dan strategi mitigasi risiko produksi keripik tempe. Industria: Jurnal Teknologi dan Manajemen Agroindustri (6)2: 88-96.

Izik Z, Dikmen I, Birgonul MT. 2011. Using Analytic Network Process (ANP) for Performance Measurament in Construction. Turki: Civil Engineering Depertment, Faculty of Engineering Middle East Technical University.

Listyati D, Herman M, Aunillah A. 2014. Prospek dan potensi pengembangan industri kakao di Indonesia. Jurnal SIRINOV (2)1: 35-46.

Mulyono D. 2016. Harmonisasi kebijakan hulu-hilir dalam pengembangan budidaya dan industri pengolahan kakao nasional. Jurnal Ekonomi Kebijakan Publik 7(2): 185-200. https://doi. org/10.22212/jekp.v7i2.417.

Nasution MFR, Yasin H. 2014. Pengaruh promosi dan harga terhadap minat beli perumahan obama PT. Nailah Adi Kurnia SEI Mencirim Medan. Jurnal Manajemen \& Bisnis 14(2): 135-143.

Putri A, Osmet, Khairati R. 2014. Pengaruh kebijakan pajak eksport (bea keluar) terhadap variabelvariabel perdagangan biji kakao Indonesia. Jurnal Agribisnis Kerakyatan (4)1: 59 - 64.

Rifin A. 2012. Competitiveness of Indonesia's cocoa beans export in the world market. International Journal of Trade, Economics and Finance (4)5: 279-281.

Risdayani. 2016. Strategi pengembangan usaha cokelat pasta pada industri rumah cokelat di Kota Palu. Jurnal Agrotekbis (4)3:361-368.

Saaty TL,Vargas LG. 2006. Decision Making with The Analytic Network Process. USA: Springer.

Simanjuntak SJ. 2013. Analisis manajemen risiko rantai pasok buah manggis dengan metode ANP di PT Agung Mustika Selaras Jawa Barat [tesis]. Bogor. Sekolah Program Pascasarjana Institut Pertanian Bogor.

Sinuriya JF, Sinaga BM, Oktaviani R, Hutabarat B. Impact of non tariff policy on cocoa export performance of Indonesia. International Journal of Sciences: Basic and Applied Research (35)3: $1-11$.

Syadullah M. 2012. Dampak kebijakan bea keluar terhadap eksport dan industri pengolahan kakao. Buletin Ilmiah Litbang Perdagangan (6)1: 5368.

Tang CS. 2006. Perspectives in supply chain risk management. International Journal Production Economics 103:451-488. https://doi. org/10.1016/j.ijpe.2005.12.006. 
Ulfah M, Maarif MS, Sukardi, Rahara S. 2016. Analisis dan perbaikan manajemen risiko rantai pasok gula rafinasi dengan pendekatan house of risk. Jurnal Teknologi Industri Pertanian (26)1: 87103.
Zulfiandri, Marimin. 2012. Strategi pengembangan agroindustri kakao berbasis kelompok tani di Provinsi Sumatera Barat. Jurnal InovisiTM (8)1: 1-13. 